\title{
Pagan Myth in Confrontation with Christianity: Skírnismál and Genesis
}

\author{
By Gro Steinsland
}

Skirnismál is the only one of the Eddaic lays which is dedicated to the god of vanir, Freyr. The poem deals with the offer of marriage to the giantess Gerdr which the messanger, Skirnir, takes to Jotunheimr on Freyr's behalf. To fulfil the wish of the god, Skirnir makes use of both seduction and curse.

Regarding the question of age and interpretation of the lay, various suggestions have been made by scholars. A central question for scholars has been whether the poem contains genuine pagan myth (Olsen 1909; cf. Dronke 1962). In recent years several scholars have argued that the lay is late and that, in spite of its preoccupation with preChristian mythology, it deals mainly with medieval ideology (Lönnroth 1978; Mitchell 1983; Bibire 1986; Randlev 1986).

Our concern here is not to provide an interpretation of the lay as such. We shall focus instead on a point which has not hitherto been recognized: the possible connection between Skirnismál and the Jewish-Christian myth of the fall in Genesis.

The dramatic structure of Skírnismál does display a striking conformity with the biblical myth of the fall, and there is, moreover, an analogy between the use of motifs in both sources witch demands further investigation.

\section{Skirnismál and Genesis}

Chapter three of Genesis conveys the Jewish-Christian myth of the fall belonging to the broader myth of creation placed within the frame of the Jahvistic lay of scripture. The myth starts with Genesis ch. 2:4 ff.

The narrative structure of the myth of the fall in Genesis may be divided into four parts:

1. The primeval state, presenting the primeval human couple in primeval conditions of life, in the fertile garden of Eden.

2. Seduction: disharmony disturbs the primeval state of harmony: a figure in the shape of a snake tempts the woman by means of a fruit which the woman accepts. 
3. Curse: man and woman are cursed and driven out of the garden.

4. A new state is anticipated: new conditions of life on earth result from the curse.

The myth of Skirnismál may be analysed as a parallel structure:

1. An original state: the god lives in Ásgarðr, the giantess lives in Jotunheimr.

2. Seduction: the balance between the two mythical worlds is disturbed by the passion of the god. On behalf of Freyr, a messenger tempts the woman with apples.

3. Curse: the woman is cursed and threatened by a life with bad conditions.

4. Transition to a new state is anticipated: the god and the giantess will be joined in the grove of barri.

The dramatic climax of the myth is constituted in both sources by a polarity between seduction and curse. The structural accord between the two sources may at first glance be claimed to be one of a common narrative character. But when the parallelism in motifs is also taken into account, a considerable conformity between the two myths emerges.

It must be emphasized that what is being considered is not merely a casual parallel between randomly chosen sources. Both Skirnismál and the myth of Genesis, in its Norse conceptions, are medieval, Norse sources. The myth of Genesis was also known beyond its literary shape through church murals and book illustrations. Pictures of Eve and the Tree of Life, the temptor and the apple(s) were known to a great number of Norsemen throughout the Middle Ages.

We shall first compare the main elements of the two myths.

\section{Genesis}

a. The snake seduces Eve

b. The couple live in the garden of Eden

c. Eve is tempted by the fruit

d. Curse:

Genesis: The woman is cursed by sexual dependence, pain and trouble (Gen ch. $3: 15$ ).

Skirnismál: The woman is cursed by sexual intercourse, ergi, oedi and ópoli (Skm sts. 29-31).

Genesis: The fertile earth is cursed to bring forth thistles (Gen ch. $3: 18)$.

\section{Skirnismál}

Skirnir seduces Gerðr

The couple will be joined

in the grove of barri

Gerðr is tempted by epli 
Skirnismál: The sexually depraved woman is symbolized by the thistle (Skm st. 31).

\section{e. Expulsion:}

Genesis: The couple are driven out of the garden (Gen ch. $3: 23-$ 24).

Skirnismál: The couple will be united in hieros gamos in the grove (Skm sts. 39 and 41).

From this short comparison it is obvious that the two sources make use of identical motifs, but that the motifs in question have the opposite function in the Eddaic lay to what they have in the biblical myth. The two sources betray a contrary tendency.

While the seducer in Genesis represents disobedience towards the god Jahve, the seducer in Skirnismál turns out to be god's own messenger. Whilst Eve's fall in Genesis means disobedience to the divine command, the wish of the god himself, causes the woman to "fall" in the Eddaic myth. Whilst the function of the curse in Genesis is to push the couple out of the garden, the function of the "fall" in Skirnismál is to get the couple into the grove. While sexuality is a kind of punishment in Genesis, sexuality is a goal in Skirnismál. In both myths the objects of the curse are driven out of an original state of existence into new conditions of life. The myth correspond to rites de passage, marking the transition from a primeval state of life to another, mature one.

The god is on the losing side in Genesis, but emerges as the victor in Skirnismál. In Genesis the fate of humanity is established through the actions of the primeval couple; death becomes a condition of life thereafter. We can imagine that the hieros gamos, which is the goal of the Eddaic myth, similarly contains fatal consequences, cf. the utterance of Freyr in stanza 7 that neither gods nor elves want a union of the two. Another Eddaic lay, Lokasenna, relates that Freyr's proposal to the giant maiden had evil consequences in the battle of Ragnargkr. Freyr is said to have lost his marvellous sword on that occasion, which means that his alliance with the giant maiden did have terrible consequences for the fate of the gods (Lokasenna st. 42).

On one point the function of motifs is consistent in both sources: as it relates to the curse upon the woman: threats and curses in both myths produce a picture of the woman as a creature in sexual dependence and distress.

From this chain of parallel motifs in Skirnismál and Genesis we will propose the hypothesis that Skirnismál is composed by a poet who 
knew the myth of Genesis and made use of his biblical knowledge in composing the Eddaic lay. We are struck, above all, by the strong polarity between seduction and curse in the two myths, as well as the common use of precise requisites such as apple and thistle. The woman is in both myths cursed by means of an apple; the thistle is in both myths the symbol of a perverted condition of life.

We have hitherto referred to the fruit of seduction as the apple; our task, then, is to investigate whether apple and thistle were known to a Nordic, medieval public as distinct elements of the biblical myth.

\section{A. Seduction by apple}

Neither the Vulgate nor the Septuagint name the fruit in the myth of the fall as an "apple". The Vulgate has fructus which means "fruit" pure and simple; The Septuagint has karpos, fruit; the Hebrew scripture has peri, fruit. It has been strongly debated what sort of fruit may be hidden in these conceptions, but the discussion is of no interest for our study. What must be stressed is that Germanic translations or commentaries which depend on the Vulgate mention the fruit as an "apple" (Roscher 1965, 1, 2; GT 1929, 6; Kuhn 1968,; Heisig 1952-53). Our concern, however, is the conceptions of the fruit used in Norse translations or compilations of the biblical myth of the fall.

Elucidarius has epli: Var vittran goðs eða illz $i$ banoðo eppli [...] (Hauksbók 1892-96, 478). Veraldar saga refers to the tree in Paradise as frodleiks tre and mentions the fruit as epli: ef pau ati epli af trenv [...] (Veraldar saga 1944, 16 ff.). Konungs skuggsia has appli: En alldin pat er tre bat barr pa heita bau froðleics apli apvi tre skulu bit acki taca oc acki noeyta af beim aplum [...] (97); Pvi nast toc hon tvau frodleics apli oc annat siolf en annat fecc hon adami [...] (98) (Konungs skuggsiá 1983, 76). Stjórn has epli: tok paa eit epli af aauexti pess sama tress ok aat [...] (ch. 11), [...] at af epla aati fengi peor langt lif [...] (Stjórn 1862, 35, 40). Lilja has epli: epli er eitt er ek banna at bita (st. 14), engi munuð it Aðám deyja andlits-hvit, poat eplit bitið [...] (st. 17), Eva hann fyr epli bannat [...] (st. 66) (Skj B, 2, 394; cf. Skj A, 2, 368; cf. Skj B, 2, 395; cf. Skj A, 2, 369; Skj B, 2, 407; cf. Skj A, 2, 384).

We may conclude that the Norsemen did know the biblical fruit of the fall as $e p l i$, that is the same sort of fruit which is used in Skirnismál for the seduction of Gerdr. The Eddaic poem actually speaks of eleven 
apples, epli ellifo, and a ring, baugr, as well in the seduction passage, and these elements should of course be analysed within the framework of Norse mythology. ${ }^{1}$ But the traditional mythical connotations of the Eddaic elements do not concern us here. In this connection we shall concentrate on the possible literary parallels between the Eddaic lay and Genesis.

\section{B. Curse and thistle}

The curse section provides the longer passage in Skirnismál, where it contains fourteen stanzas (Skm sts. 23-36, of which Skm sts. 26-36 constitute the curse proper).

Curse and compulsions are the means used by Skirnir because the giantess refuses the offer of marriage from the god. We should recall her proud utterance before Skirnir has shown his mighty weapons of compulsion:
Ánauð bola
Compulsion
ek vil aldregi
I will never stand

But the curses and compulsions of Skirnir make Gerdr's pride and independence collapse. The curse section is the one most frequently commented on by scholars, but we shall not discuss the passage per se here. Gerðr's life will be like that of a dead person; all the world will repel her, she herself will be disgusted by food (Skm sts. 26-28), until she will at last find herself in the hall of pursir, in pain and insanity, and here she will be sexually exploited. And at the same time, she herself will develop sexual abnormalities. (Skm sts. 29-31).

The perverted conditions by which Gerðr is threatened, is symbolised in the picture of the thistle in $S k m$ st. 31:

Ver pú sem pistil

Become you as the thistle

Early sholarly analyses of Skirnismál did not pay much attention to the curse passage. It seems that the god Freyr alone held the sympathy of the interpreters, and there was a tendency to overlook the wretched fate of the woman and the violence with which she is treated. This is the scope of the interpretation proposed by Magnus Olsen

1 Many sholars have followed an emendation from epli ellifo, eleven apples, to epli ellilyf, apples as remedies of long life, first published by Svend Grundtvig in 1874 . The proposal is based on the myth of Iðunn in Haustlong. Grundtvig 1874. 
(Olsen 1909) and also in Jöran Sahlgren's analyses (Sahlgren 192728). Later scholars, however, have paid close attention to the curse section; Ursula Dronke, for example, considers the passage as a main element of the poem (Dronke 1962); as do Lars Lönnroth (Lönnroth 1978), Stephen Mitchell (Mitchell 1983), Julie Randlev (Randlev 1986) and Paul Bibire (Bibire 1986).

The motif of the thistle in st. 31 stands out as the quintessence of whatever Gerdr is threatened by. ${ }^{2}$ The weed symbolizes the opposite of mature womanhood; the thistle is a symbol of dryness and death in contrast to fertility and life, evoking the life of an outcast rather than a fully integrated member of society.

\section{The thistle in Genesis}

The thistle as a symbol of cursed conditions of life is also found in the myth of the fall in Genesis. Here, the earth is cursed by God as a result of the fall of Eve and Adam. When Jahve has learned to know the offence of the primeval couple, the following punishment is uttered (Gen ch. 3:17-18, Vulgate):

Quia audisti vocem uxoris tuce, et comedisti de ligno, ex quo, precepebam tibi, ne comederes, maledicta terra in opere tuo: in laboribus cemedes ex ea cunctis diebus vita tuc. Spinas et tribulos germinabit tibi, et comedes herbam terre.

Because thou hast hearkened unto the voice of thy wife, and hast eaten of the tree, of which I commanded thee, saying, Thou shalt not eat of it: cursed is the ground for thy sake; in sorrow shalt thou eat of it all the day, of thy life; Thorns also and thistles skall it bring forth to thee; and thou shalt eat the herb of the field.

(Authorised version)

For spinas et tribulos in the Vulgate, the Septuagint has akantas kai tribulos. Latin spina, f., means thorn, bramble; tribulus m., means thistle; Greek and Latin reproduce the Hebrew dardar, the main word for thistle (Buttrick 1981). In Stjórn, the Norse compilation of the Old Testament, spinas is rendered with born ok klungr, thorns and brambles (Stjórn 1862,38). None of the interpretations of Genesis

2 So also Joseph Harris: "Thus the thistle simile seems to stand as a summary, reflecting but not participating in the categories of the conceptual structure of the curse...". Harris 1975, 33. 
which the compiler of Stjórn refers to, mention the plant; neither for Scholastica historia, Speculum historiale or for Augustinus does the compiler refer to any sort of herb.

Actually porn ok klungr is identical with spinas et tribulos. The translator or compiler certainly did know the plant from other biblical texts: thistles and thorns are commonly used as metaphors in the Old Testament, often as metaphors of punishment of $\sin$ (Jos. 23, 13; Job 31, 40; Isa. 5, 6; Isa. 32, 13; Hos. 9, 6; Hos. 10, 8; Mic. 7, 4), as pictures of disobedience (2 Sa. 23, 6; 2 Ki. 14, 9; Song of S. 15, 9), as a symbol of pain and grief (Song of S. 26, 9; Ez. 28, 24), and where cultivating of land is concerned - the thistle is a symbol of mismanagement of the land (Song of S. 24, 31). It is obvious that the use of tribulos in Genesis is in concordance with the common use of metaphors in the Old Testament.

Konungs skuggsia on the other hand, use pistill for tribulos in Genesis: pistla oc illgrasi skal hon gefa ber iavoxt, thistles and weed it shall bring you as crop (Konungs skuggsiá 1983, 108). Konungs skuggsiá is dated to about 1250; as a source it is older than Stjórn, and it is interesting that in the rendering of the curse of Genesis it makes use of the term pistill, the same word which in Skirnismál st. 31 is use as a symbol of the cursed, perverted life.

The conclution is that the Northmen did know the polarity between seduction and curse, and also the distinct motifs of apple and thistle, as elements of the biblical myth of the fall.

Inevitably the mythical elements in Skirnismál must be analysed within the frame of pagan mythology. What we have pointed out here is a concordance between Skirnismál and Genesis in the polarity within the narrative structure of two myths and a concordance between certain distinct motifs: apple as a means of seduction and thistle as a symbol of the cursed state of existence. In the myth of the fall in Genesis it is the earth which is cursed to bring forth thistles; in the Eddaic lay it is the Gerdr who is cursed to become like a thistle. According to Magnus Olsen's interpretation of Skirnismál, Gerðr is a personification of the earth (Olsen 1909).

It has been pointed out that the thistle motif has had a traditional function in Germanic runic formulae (Olsen 1964, 41 f.) Joseph Harris has argued strongly for a Germanic provence of the thistle motif used in Skirnismál (Harris 1975). But it is not the traditional Germanic kind of formula which Skirnismál exhibits; the motif has a function within a complex mythical narrative. Possibly both pre-Christian tradition and allusions to the biblical myth are mingled in the Eddaic lay. 


\section{Hypothesis}

a) Hypothetically, one may propose that the poet of Skirnismál has used his knowledge of the Jewish-Christian myth of the fall and applied it within the frame of a poem which mainly makes use of pagan elements. Then the Eddaic lay exhibits some sort of transformation. The structure and certain main motifs of the biblical myth are recognizable within the Eddaic lay, but both the structure and the elements are transformed.

The transformation may be explained by artistic needs alone; a Norse poet has been artistically inspired by the biblical myth and has mixed elements from the Old Testament narrative with domestic mythical traditions.

b) Another explanation emerges from the medieval principle of interpretation. The Old Testament was typologically interpreted in the Middle Ages; the principle is prefiguration: Old Testament typus prefigures New Testament anti-typus as Adam prefigures Christ. This principle of interpretation justifies and allows the incorporation of pagan traditions into a world history which is still ruled by God, thereby providing a teleological history. ${ }^{3}$

Hypothetically, it might be proposed that a medieval poet quite familiar with the sholarly principles of interpretation could recreate pagan myths as parallels to the biblical, Old Testament prefigurations. Thus paganism had to be defended in the same way as Judaism, as a forerunner of Christianity. A "pagan" myth may have been produced as a parallel to the myth of fall in Genesis. With this explanation, however, no justice is made to Skirnismál's strong opposition to the myth of Genesis as far as tendency is concerned.

c) A more reliable explanation of the special function of the biblical motifs which we have recognized in Skirnismál, is that the poet has made use of biblical elements to create a distance to the biblical myth. One may propose that the use of biblical elements in the Eddaic poem represent a biased interpretatio norroena of the myth of Genesis. A Norse poet has used the biblical motifs in an extremely independent manner. In the Eddaic lay, it is the god who - through his own messenger - functions as a seducer and makes the woman "fall".

${ }^{3}$ Gerd Wolfgang Weber has exemplified the use of the typological interpretation in several articles. Cf. Weber 1987. 
But Skirnismál's obvious opposition to the biblical myth as regards tendency still does not seem to have received a full explanation.

d) A reinterpretation which must be called a remythologization of the myth of Genesis, has been known since the first centuries among gnostic heretical sects. The mythology of creation and fall particularly concerned the Gnostics. From their experience of a supreme, trancendental god, the Gnostics proclaimed to unveil the lower, ignorant god of creation. They were thereby able to claim freedom with regard to Scripture and tradition. A consequence of this freedom was remythologization of traditional myths.

The Gnostics, for example, recognized the serpent in the myth of the fall in Genesis as a forerunner of the Saviour; the apple which was offered to Eve by the serpent contained gnosis, the deeper, saving knowledge which made man able to grasp his true nature and thereby his salvation. Correspondingly, the apples which are offered to Gerdr, contain access to the world of gods through marriage with Freyr.

An element which may support the view that Skirnismál reflects knowledge of gnostic reinterpretation of the myth of the fall in Genesis is the name of the messenger, Skirnir. He is only known in Skirnismál, except for one occurrence in Snorri's Gylfaginning. The name has usually been interpreted as "light", cf. old Norse skirr, light, bright. Scholars have seen the messenger as a personification of Freyr himself who in Grimnismál 43 is called skirr Freyr. But what has not been realized, is that the name may be explained formally as a nomen agentis to skirn, f., which is commonly used in medieval litterature of Convertion in the meaning "baptism"." Skirnir may be interpreted as "Baptizer", he then turns out to be a pagan parallel to the Baptist, the forerunner of the Saviour, a first messanger who in genuine gnostic manner is placed within the frame of the primeval history.

The name Skirnir interpreted in the conventional way as the bright, shining one, also fits in with gnostic metaphors of light.

The gnostic model of remythologization which we have focused as a possible model working for the Norse poet of Skirnismál, may seem very far-fetched if no point of reference in the Nordic medieval history can be singled out.

There are, however, sources which may support the possibility of gnostic influence in Scandinavia in the eleventh century. Islendingabók 8 describes ermskir bishops who stayed in Iceland at the time

4 For this interpretation of Skirnir I am indebted to Prof. Else Mundal, University of Oslo. 
of bishop Isleifr. The source describes so-called episcopi vaqantes: Petrus, Abraham and Stephanus (Íslendingabók 1986, 18). Ari does not point out a certain date for their activity in Iceland, but he seems be referring to the same bishops as those mentioned in Hungrvaka 2 (Byskupa sggur 1938, 25-115). The latter are foreign bishops, condemned by the Archbishop, Adalbert of Bremen. He did prohibit people from making use of the services of these non-consecrated bishops who were disgracefully ordained for money in England or France, in Anglia vel in Gallia, and who apparently preached "another and easier doctrine" than the priests of Bremen (Cf. Adam 1917, III, c. 16, shol. 69 (70) [Letter from Pope Alexander II to King Harald the Hardruler]; cf. DN 1847, 17, nr. 1). The time of their activity in Iceland must have been between 1056-1072. Grágás also refers to the ermskir bishops (Grágás 1974, 1a, 22; Grágás 1974, 2, 27), those who have not learned the Latin tongue and about whom the people are warned. ${ }^{5}$

At the end of the ninteenth century, the Danish sholar of ecclesiastical history, A. D. Jørgensen, identified the ermskir as Paulicians, an heretic group which seems to have arisen in Armenia in the seventh century and which achieved a tremendous importance, also being disseminated to Europe (Jørgensen 1874-78). Jørgensen refers to the known connections between the Norwegian King Harald the Hardruler and the Russian Church and the unconsecrated bishops which the king, according to tradition, is supposed to have brought to Scandinavia. ${ }^{6}$

The Icelandic historian Jón Jóhannesson follows the view of Jørgensen in identifying the ermskir as Paulicians (Jóhannesson 1969). Mágnus Már Lárusson however, associates the ermskir bishops with Ermland in Gardarike. His interpretation also points to connections with the Eastern Church (Lárusson 1959).

The Paulicians represent an obvious gnostic Ch ristian doctrine which separated the divine into a higher, transcendent god and a lower god of creation. Like all Gnostics, they practised great freedom in interpretation of Holy Scripture.

Our sources regarding the activity of these gnostic bishops are scanty, but the little information there is may reflect the realities and thereby suggest important circumstances: medieval Scandinavia did not rep-

\footnotetext{
${ }^{5}$ Grágás 1974, 1a, 22 has hermskir; cf. Grágás 1974, 3, 330 f.; Grágás 1974, 2, 27 has ermskir; Grágás 1974, 3, 24 has enskir; Grágás 1974, 3, 117 has armskir.

6 Cf. diploma from Pope Alexander to the King Harald the Hardruler. Adam 1917, III, c. 16, shol. 69 (70).
} 
resent a homogenous Christian dogma. Our sources support a hypothesis that gnostic, heretical traditions of interpretation may have reached the Nordic countries through the activity of foreign clergy as early as the eleventh century. ${ }^{7}$ The activity of the three bishops named may have been one of several possible channels of heretical influence in the North. ${ }^{8}$

From what is written above we dare to maintain the hypothesis which says that the poet of Skirnismál borrowed ideas from several traditions, from Nordic, mythological ones and at the same time from biblical tradition, from the myth of the fall in Genesis, whether this is from knowledge of a sholarly, typological method of interpretation or from knowledge of a heretical, gnostic meaning of the myth.

This conclusion means that the pagan, mythological tradition of the North was recreated at the time of Conversion, for the biblical elements in Skirnismál are used within the frame of a lay which, in its deepest conception, belongs to the pre-Christian tradition. The interpretation of the Eddaic lay as such, however, is another and greater task, reserved for a more extensive study. In this collocation of the Eddaic lay and the myth of Genesis we have suggested one possible layer of tradition, one thread in the texture constituted by Skirnismál. These viewpoints are of great importance, however, in the question of dating and also, thereby, of interpretation, besides adding to our understanding of the surroundings in which the Eddaic poems were created.

\footnotetext{
7 We are here in opposition to Peter Foote's viewpoint on the problem of syncretism in the time of Conversion in Iceland. Foote concludes as follows: "Differences must have existed, though hardly at fundamental doctrinal level". Foote 1984, 88.

8 Bearing in mind that the Gnostics were extremely occupied by the mythology of creation, a demonstration of gnostic influence in the North could explain the gnostic tendency which seems to exist in the anthropogonic myth of Voluspá. Cf Steinsland 1983.
} 


\title{
Bibliography
}

\author{
AbBREviations
}

Gen Genesis

Skm Skirnismál

Adam of Bremen. 1917. Magistri Adam Bremensis Gesta Hammaburgensis Ecclesiae Pontificum. Hrsg. von B. Schmeidler. Hannover.

Bibire, P. 1986. Freyr and Gerdr: The story and its myths. Sagnaskemmtun. Ed. by R. Simek et al. Wien.

Buttrick, G. A. 1981. Thistle, Thorn. The interpretator's dictionary of the Bible. Abingdon.

Byskupa şgur 1. 1938. [Ed. by] J. Helgason. (Det kgl. nordiske Oldskriftselskap). København.

DN Diplomatarium Norvegicum 1. 1847. [Ed. by] Chr. C. A. Lange \& C. R. Unger, Christiania.

Dronke, U. 1962. Art and tradition in Skírnismál. English and medieval studies presented to J. R. R. Tolkien. By N. Davies et al. BLondon.

Foote, P. 1984. Observations on "syncretism" in early Icelandic Christianity. Aurvandilstá. [Ed. by] M. Barnes \& H. Bekker-Nielsen \& G. Weber. (The Viking Collection 2.) Odense.

Grágás Ia-b-3. (1852-83). [Ed. by] V. Finsen. Odense.

Grundtvig, S. 1874. Semundar Edda hins fróða. 1-3. København.

GT Det gamle testamente 1. 1929. [Transl. by] S. Michelet \& S. Mowinckel \& N. Messel. Oslo.

Harris, J. 1975. Cursing with the thistle. Neuphilologische Mitteilungen 76. Helsinki.

Hauksbók. 1892-96. [Ed. by] F. Jónsson. København.

Heisig, K. 1952-53. Woher stammt die Vorstellung vom Paradiesapfel. Zeitschrift für die Neutestamentliche Wissenschaft und die Kunde der älteren Kirche 44. Berlin.

Íslendingabók. Íslendingabók. Landnámabók. 1968. [Ed. by] J. Benediktsson. (Íslenzk fornit 1.) Reykjavík.

Jóhannesson, J. 1969. Islands historie i mellomalderen. Oslo.

Jørgensen, A. D. 1874-78. Den nordiske Kirkes Grundlaggelse og første Udvikling 1. København.

Konungs skuggsiá. 1983. [Ed. by] L. Holm-Olsen. (Norrøne tekster 1.) Oslo. Kuhn, H. 1968. Apfel. Reallexikon der germanischen Altertumskunde 1. Hrsg. von $\mathrm{H}$. Beck et al. Berlin.

Lárusson, M. M. 1959. Um hina ermsku biskupa. Skírnir 133. Reykjavík. 
Lönnroth, L. 1978. Skírnismál och den fornisländska äktenskapsnormen. Opuscula Septentrionalia. [Ed. by] B. Chr. Jacobsen et al. Hafniae.

Mitchell, S. 1983. For Skirnis as Mythological Model: frið at kaupa. Arkiv för nordisk filologi 98 . Lund.

Olsen, M. 1909. Fra gammelnorsk myte og kultus. Maal og Minne. Kristiania.

- 1964. Edda- og skaldekvad 7. Oslo.

Randlev, J. 1986. Skírnismál. Maal og Minne. Oslo.

Roscher, W. H. 1965. Ausführliches Lexikon der griechischen und römischen Mythologie 1-7. Hildesheim.

Sahlgren, J. 1928. Eddica et Scaldica 2. (Nordisk filologi 1:2.) Lund.

Skj Den norsk-islandske Skjaldedigtning A 1-2, B 1-2. 1967-73 (1912-15). [Ed. by] F. Jónsson. København.

Steinsland, G. 1983. Antogonimyten i Voluspá. Arkiv för nordisk flologi 98. Lund.

Stjórn. 1862. [Ed. by] C. R. Unger, Christiania.

Samundar Edda hins fróda. 1965 (1867). [Ed. by] S. Bugge. Oslo.

Veraldar saga. 1944. [Ed. by] J. Benedilitsson. København.

Vulgata. 1970. London.

Weber, G. W. 1987. Intellegere historiam. Tradition og historieskrivning. [Ed. by] K. Hastrup \& P. Meulengracht Sørensen. (Acta Jutlandica 63, 2; Acta Jutlandica. Humanistisk serie 61.) Århus. 